\title{
“Post Coronavirus Disease (COVID-19) Reactivation of a Quiescent Unilateral Anterior Uveitis"
}

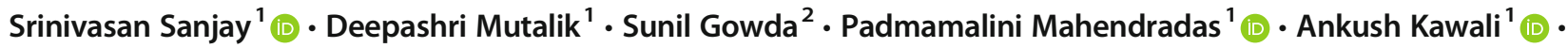 \\ Rohit Shetty ${ }^{3}$ (I)
}

Accepted: 1 June 2021 / Published online: 7 June 2021

(C) The Author(s), under exclusive licence to Springer Nature Switzerland AG 2021

\begin{abstract}
Coronavirus disease (COVID-19) can be associated with ophthalmic manifestations like conjunctivitis, retinal haemorrhages, retinal vascular occlusions, papillophlebitis, and Adie's syndrome. We herein report for a case of a unilateral acute anterior uveitis which was quiescent for 13 years and was reactivated post COVID-19 infection in a 43-year-old Asian Indian male. He had a past history of recurrent unilateral granulomatous anterior and intermediate uveitis in the right eye (RE), and all the investigations done 14 years ago were negative and had been on treatment with topical and oral steroids. He developed cataract 6 months later in the RE and underwent surgery. Patient was in remission for the past 13 years. Uveitis investigations for the present episode were all negative. Topical steroid and cycloplegic helped in resolution of the uveitis. This may be the first instance of reactivation of a quiescent unilateral anterior uveitis following COVID-19 infection.
\end{abstract}

Keywords Corona virus disease (COVID-19) · Anterior uveitis · Reactivation · Severe acute respiratory syndrome (SARS-CoV2) antibodies $\cdot$ Leucopenia

\section{Introduction}

Ophthalmic manifestations reported secondary to coronavirus disease (COVID)-19 infection include conjunctivitis, conjunctival hyperaemia, chemosis, epiphora, cotton wool spots (CWS) retinal haemorrhages, dilated and tortuous vessels, retinal artery/vein occlusion, ophthalmic artery occlusion, panuveitis and papillophlebitis, and multifocal chorioretinitis [1-8].

We would like to report for the first time a case of a unilateral acute anterior uveitis which was quiescent for 13 years and reactivated post COVID-19 infection.

This article is part of the Topical Collection on Covid-19

Srinivasan Sanjay

sanjaygroup24@gmail.com

1 Department of Uvea and Ocular Immunology, Naryana Nethralaya, Bangalore, India

2 Department of Ear, Nose and Throat, St Martha's Hospital, Bangalore, India

3 Department of Neuro-ophthalmology, Cornea and Refractive Surgery, Narayana Nethralaya, Bangalore, India

\section{Case Report}

A 43-year-old Asian Indian male doctor, by profession, presented to us with unilateral redness and blurring of vision in the right eye (RE), 15 days after being diagnosed with COVID-19.

The patient had myalgia 17 days earlier, prior to the ocular presentation. Considering his active professional life, he selftested for COVID-19 using real-time polymerase chain reaction (PCR), which was positive, and B-beta (coronavirus) $\mathrm{CoV}$-specific target gene and severe acute respiratory syndrome coronavirus-2 (SARS-CoV-2)-specific target genes were detected.

The investigations done the following day after the diagnosis of COVID-19 are shown in Table 1. He was started on oral steroids $40 \mathrm{mg}$ OD for 3 days and $20 \mathrm{mg}$ OD for 3 days elsewhere and then stopped as there were no other symptoms.. The patient was under home quarantine for 2 weeks following the COVID-19 diagnosis.

Fourteen years earlier, he had been diagnosed to have recurrent unilateral granulomatous anterior and intermediate uveitis in the RE elsewhere. Investigations done during that period were complete blood count (CBC), erythrocyte sedimentation rate (ESR), peripheral blood smear, C-reactive 
Table 1 Investigations done during and after COVID-19 infection

Investigations done at the time of diagnosis of COVID-19

\begin{tabular}{|c|c|c|}
\hline D-dimer & 0.2 & \\
\hline Lactose dehydrogenase (LDH) & 205 & (12-60 years $100-190$ units/l) \\
\hline Serum ferritin & 31.65 & (20-250ng/ml) Immunoturbidimetry \\
\hline Chest X-ray & Normal & \\
\hline $\begin{array}{l}\text { High-resolution computerized tomography of the chest } \\
\text { done } 6 \text { days later }\end{array}$ & Normal & \\
\hline \multicolumn{3}{|c|}{ Investigations done 1 week after diagnosis of COVID-19 after starting oral steroids } \\
\hline C-reactive protein (CRP) & $0.6 \mathrm{mg} / \mathrm{L}$ & $(<5 \mathrm{mg} / \mathrm{L})$ by immunoturbidimetric assay \\
\hline Serum ferritin & $51.7 \mathrm{ng} / \mathrm{ml}$ & $\begin{array}{l}(30-400 \mathrm{ng} / \mathrm{ml}) \text { by electrochemiluminescence } \\
\text { immunoassay( ECLIA) method }\end{array}$ \\
\hline D-dimer & $157.31 \mathrm{ng} / \mathrm{ml}$ & (0-500ng/ml) by enzyme-linked fluorescence assay (ELFA) \\
\hline \multicolumn{3}{|l|}{ Tests done at the time of ocular presentation } \\
\hline CRP & $1.74 \mathrm{mg} / \mathrm{L}$ & $(<5 \mathrm{mg} / \mathrm{L})$ by immunoturbidimetric assay \\
\hline Serum ferritin & $43 \mathrm{ng} / \mathrm{ml}$ & $(30-400 \mathrm{ng} / \mathrm{ml})$ by ECLIA method \\
\hline D-dimer & 0.2 & (by immunoturbidimetric assay $(<0.5 \mathrm{mcg} / \mathrm{ml} \mathrm{FEU})$ \\
\hline Procalcitonin & 0.044 & $<0.05$, normal \\
\hline $\mathrm{LDH}$ & 233 & (12-60 years, $100-190$ units/l) \\
\hline Peripheral blood smear & Normal & \\
\hline COVID antibody & 6.3 & $<1$ \\
\hline Fasting blood sugar (FBS) & 98 & $90-120 \mathrm{mg} / \mathrm{dl}$ \\
\hline CRP & 1.3 & $<5 \mathrm{mg} / \mathrm{ml}$ \\
\hline Complete blood count (CBC) - Eosinophils & $\begin{array}{l}7 \%, \text { rest of all parameters } \\
\text { were normal }\end{array}$ & $0-6 \%$ \\
\hline HIV 1 and 2 & Non-reactive & ELISA \\
\hline Anti-hepatitis $\mathrm{C}$ virus antibody & Non-reactive & \\
\hline Urine analysis & Normal & \\
\hline $\mathrm{LDH}$ & 206 & (12-60 years, $100-190$ units/l) \\
\hline Serum angiotensin-converting enzyme & 24.3 & $14-62$ \\
\hline Treponema pallidum haemagglutination antibody & Non-reactive & \\
\hline Serum vitamin $\mathrm{D}$ & 16.8 & $(>30)$ \\
\hline Serum ferritin & 30.6 & $(30-400 \mathrm{ng} / \mathrm{ml})$ ( ECLIA) method \\
\hline HLA-B27 & Negative & \\
\hline ANA & Negative & \\
\hline Mantoux & Negative & \\
\hline Leptospira IgG & Negative & ELISA \\
\hline
\end{tabular}

protein (CRP), chest X-ray, and serum angiotensin-converting enzyme (ACE) which were all normal. Mantoux, HLA- B27, and ANA were negative. RE ultrasound biomicroscopy of the pars plana area showed inferior ciliary body thickening and presence of inferior vitreous and pars plana membranes which were suggestive of inflammation (based on his old medical records). Aqueous humour paracentesis in the RE for (polymerase chain reaction) PCR for herpes simplex, leptospira, and mycobacteria were all negative. He was treated with oral steroids $40 \mathrm{mg}$ in tapering dose and also received posterior sub-tenon's injection of triamcinolone acetate $40 \mathrm{mg}$ by the uvea specialist then. He had 3 more episodes of anterior uveitis in the RE, over a period of 6 months which were treated by topical and systemic steroids. He had been advised oral methotrexate $15 \mathrm{mg}$ by the local rheumatologist, but patient had declined the same .He developed posterior subcapsular cataract in his RE, 6 months after the initial onset of his ocular inflammation and was operated 13 years back with a posterior chamber intraocular lens. For the past 13 years, he had no ocular symptoms. He had no other systemic history of note.

Fifteen days after COVID-19 infection, he developed pain and redness in the right eye (RE).

Presently, on his ophthalmic evaluation, his best-corrected visual acuity (BCVA) for distance was 20/20 in RE and 20/20 in the left eye (LE). The intraocular pressures were $18 \mathrm{mmHg}$ in both the eyes (BE). There were no keratic precipitates 
unlike the previous episode. Anterior chamber (AC) of the RE had flare $2+$ cells $2+$, pseudophakia with peripheral posterior capsule opacification and anterior vitreous showed cells $1+$. There was no evidence of heterochromia. There was no evidence of snowbanking or pars plana membranes. RE fundus showed early epiretinal membrane (ERM) with normal retinal periphery. LE fundus was normal. Anterior chamber paracentesis was not considered as the patient was not keen.

Based on the clinical findings, a diagnosis of reactivation of right eye acute anterior uveitis was made. The patient was started on topical prednisolone acetate $1 \% 3$ hourly with homatropine $2 \%$ twice daily in RE and suggested tapering of the topical steroids over a month. Systemic investigations done during this episode were within normal limits (Table 1). COVID-19 IgG antibodies were raised.

At 1 month follow-up, the patient was symptomatically better in RE with BCVA of 20/20 and had no cells in the $\mathrm{AC}$ and anterior vitreous with normal fundus.

\section{Discussion}

We describe a case of reactivation of unilateral acute anterior uveitis who had just recovered from COVID-19. All investigations for ascertaining the cause of uveitis were all negative as indicated in Table 1.

Severe acute respiratory syndrome corona virus-2 (SARSCoV-2) has been detected in ocular secretions although the exact pathophysiology of ocular transmission of the virus remains incompletely understood. The ocular tropism of the virus and its potential to cause localized ocular disease are worth considering [9]. In SARS-CoV-2 infection, there are two types of responses. The initial response is from the innate immune system which provides the first line of defence and the adaptive immune response by cytotoxic T cells and B cells by producing neutralizing antibodies to SARS-CoV-2 [10].

\section{Innate Immune System}

SARS-CoV-2 spike (S) protein binds to angiotensinconverting enzyme (ACE) 2 and may enter the cell either via endocytosis and cathepsin L (CTSL)-dependent viral escape from the endosome - which is augmented by transmembrane serine protease 2 (TMPRSS2) or by TMPRSS2dependent direct fusion of the viral envelope with the cell membrane [11-13]. Intracellular cascade signalling result in activation of transcription factors such as nuclear factor-kappa $\mathrm{B}(\mathrm{NF}-\mathrm{KB})$ and interferon regulatory factors (IRFs) [14] which lead to the production of type I interferons (IFNs) and proinflammatory cytokines.

Spuntarelli et al. in their review article noted that COVID19 affected multiple organ systems including respiratory, cardiac, renal, hepatobiliary, nervous, and possibly reproductive system especially in the males [15].

An adequate IFN response normally induces an anti-viral immune state in infected cells that limits viral replication and induces apoptosis to protect the host from viral dissemination. However, multiple SARS-CoV-2 proteins have been shown to suppress antiviral type I IFN (IFN-I) production and signalling [16-19]. The initial delay of the IFN-I response is followed by unrestrained viral replication and dissemination in the infected host. Later an eventual increase of IFN-I can exacerbate hyper-inflammation in the progression to severe disease due to increased pro-inflammatory cytokine response. [20, 21]

\section{Adaptive Immune Response}

Adaptive immune response occurs due to either activated cytotoxic T cells that destroy infected cells or through B cells that produce neutralizing antibodies against virus-specific antigens.

COVID-19-associated lymphopenia may be due to reduced T lymphocytes and B cells [22].

Postulated mechanisms for lymphopenia include abnormal innate immune response featuring low IFN-I, considering its essential role in the assembly of viral material for antigen presentation and the subsequent induction of adaptive immunity [23], direct SARS-CoV-2 infection of T-cells [24, 25], cytokine-induced apoptosis and pyroptosis of lymphocytes [26], macrophage activation syndrome(MAS)-related haemophagocytosis, lymphocyte sequestration in the lungs or other organs [27], reduced bone marrow haematopoiesis [28], and virus-induced tissue damage of lymphatic organs $[29,30]$.

The possible explanations for the increased risk of uveitis in post COVID-19 patients could be due to the ocular inflammation triggered by the increased systematic inflammatory burden. Autoimmune diseases can flare up after viral infections especially in genetically susceptible individuals. The postulates for reactivation of an ocular inflammation by the viruses could be due to break down of the self-tolerance by "molecular mimicry" and "bystander activation." Nonspecific and an over-reactive antiviral immune response creates a localized pro-inflammatory environment leading to the release of self-antigens from the damaged tissue. These selfantigens are subsequently taken up and presented by antigenpresenting cells (APC) to stimulate the auto-reactive T cells in the vicinity triggering autoimmunity. This is called "bystander activation" [30]

Viruses can be direct aetiologic agents of acute and chronic arthritis [31] and of different forms of vasculitis, both in children and adults [32]. Identifying an infectious aetiology can be extremely challenging although the causal relationship between a viral trigger and rheumatic diseases is well-known [33]. Since symptoms of potential rheumatologic interest have 
been frequently reported in COVID-19 patients, the new virus outbreak represents a previously unseen differential diagnosis to be henceforth taken into consideration. [33] Our patient had myalgia which can be associated with COVID-19 during initial phases or later in the disease [33].

Autoantibodies are seen in patients with COVID-19. The autoantibodies which have been detected include anti-52 kDa SSA/Ro antibody, anti-60 kDa SSA/Ro antibody, antinuclear antibody, and anti-phospholipid antibodies, (and in particular anticardiolipin IgA, anti- $\beta 2$-glycoprotein I IgA and $\operatorname{IgG}$ ) [33-35].

SARS-COV-2 infection alters coagulation pathway. Zhou et al. demonstrated that nonsurvivor COVID-19 patients show significant higher levels of plasma D-dimer and activated partial thromboplastin times and prothrombin times compared with survivors [36]. Our patient had mild elevation of DDimer at the time of COVID-19 diagnosis and the rest of the parameters were within normal limits (Table 1).

Multiple cytokines such as IL-1b, IFN- $\gamma$, TNF- $\alpha$, IL-4, IL10, IL-8, IL-9, and IL-6, are released during COVID-19 infection $[37,38]$. Both pro-inflammatory cytokines and anti-inflammatory cytokines are released but the balance of this immune response in patients with COVID-19 determines the manifestations. [39]

Luciani et al. reported a patient with acute tuberculosis infection superimposed on COVID-19 pneumonia [40]. They hypothesized that trained immunity can also exert protective actions against COVID-19. In countries that do not have a universal vaccination policy against the BCG, such as Italy and the USA, a higher mortality associated with COVID-19 has been reported [40].

Moving forward, Bacille Calmette Guérin (BCG), vaccines represent a major resource for public health, and it has been suggested that BCG vaccine may protect individuals against COVID-19 infection [41]. Our patient had received BCG vaccine during his childhood, if this had a role in the present inflammation is just a matter of speculation.

A clinical report of acute anterior uveitis associated with follicular conjunctivitis in a patient who was tested positive for SARS-CoV-2 has been reported although anterior chamber had only flare with inflammatory deposits on the lens. Interesting to note in this case was leucopenia. Leucopenia is one of the manifestations of the haematological changes induced by SARS-CoV-2 [42]. Our patient did not have leucopenia post COVID-19 infection (Table 1). Patients with uveitis may show a mild increase or leukocytosis may be the norm.

\section{Conclusion}

We hereby describe a patient with anterior uveitis which was quiescent for 13 years and reactivated after COVID-19 infection. This may be the first instance of reactivation of a quiescent anterior uveitis following COVID-19 infection which is being reported. COVID-19 can affect the ocular structures even after complete recovery.

Availability of Data and Material Data available on request. Code Availability Not applicable.

Authors' Contributions Srinivasan Sanjay: Design, acquisition of data, analysis and interpretation, manuscript writing, manuscript editing, intellectual content

Deepashri Mutalik: Acquisition of data, analysis and interpretation, manuscript writing, manuscript editing, intellectual content

Sunil Gowda: Acquisition of data, manuscript writing

Padmamalini Mahendradas: Design, analysis and interpretation, manuscript writing, manuscript editing, intellectual content

Ankush Kawali: Analysis and interpretation, manuscript writing, manuscript editing, intellectual content

Rohit Shetty: Design, manuscript editing

\section{Declarations}

Ethics Approval Approved by the ethics committee of Narayana Nethralaya where the study was done. Ethics Committee approval number: $\mathrm{C} / 2020 / 09 / 09$.

Consent to Participate All the patient's written consent was obtained for participating in the study.

Consent for Publication Patient's written consent was obtained for publication purposes.

Conflict of Interest The authors declare no conflict of interest.

\section{References}

1. Wu P, Duan F, Luo C, Liu Q, Qu X, Liang L, et al. Characteristics of ocular findings of patients with coronavirus disease 2019 (COVID-19) in Hubei Province, China. JAMA Ophthalmol. 2020;138:575-8. https://doi.org/10.1001/jamaophthalmol.2020. 1291.

2. Acharya S, Diamond M, Anwar S, Glaser A, Tyagi P. Unique case of central retinal artery occlusion secondary to COVID-19 disease. IDCases. 2020;21:e0867.

3. Insausti-García A, Reche-Sainz JA, Ruiz-Arranz C, López Vázquez Á, Ferro-Osuna M. Papillophlebitis in a COVID-19 patient: Inflammation and hypercoagulable state [published online ahead of print Eur J Ophthalmol 2020 2020;1120672120947591.

4. Landecho MF, Yuste JR, Gándara E, Sunsundegui P, Quiroga J, Alcaide AB, et al. COVID-19 retinal microangiopathy as an in vivo biomarker of systemic vascular disease? J Intern Med. 2020. https:// doi.org/10.1111/joim.13156.

5. Dumitrascu OM, Volod O, Bose S, Wang Y, Biousse V, Lyden PD. Acute ophthalmic artery occlusion in a COVID-19 patient on apixaban. J Stroke Cerebrovasc Dis. 2020;29:104982.

6. Ortiz-Seller A, Martínez Costa L, Hernández-Pons A, Valls Pascual E, Solves Alemany A, Albert-Fort M. Ophthalmic and neuroophthalmic manifestations of coronavirus disease 2019 (COVID19). Ocul Immunol Inflamm. 2020;28:1285-9. 
7. Sanjay S, Srinivasan P, Jayadev C, Mahendradas P, Gupta A, Kawali A, et al. Post COVID-19 ophthalmic manifestations in an Asian Indian male. Ocul Immunol Inflamm. 2021;18:1-6. https:// doi.org/10.1080/09273948.2020.1870147.

8. Sanjay S, Gowda PB, Rao B, Mutalik D, Mahendradas P, Kawali A et al. "Old wine in a new bottle" - post COVID-19 infection, central serous chorioretinopathy and the steroids. J Ophthalmic Inflamm Infect. 2021;11(1):14. https://doi.org/10.1186/s12348-021-002444.

9. Ho D, Low R, Tong L, Gupta V, Veeraraghavan A, Agrawal R. COVID-19 and the Ocular Surface: A Review of Transmission and Manifestations. Ocul Immunol Inflamm. 2020;28(5):726-34. https://doi.org/10.1080/09273948.2020.1772313.

10. van Eijk LE, Binkhorst M, Bourgonje AR, Offringa AK, Mulder DJ, Bos EM, et al. COVID-19: immunopathology, pathophysiological mechanisms, and treatment options. J Pathol. 2021. https://doi. org/10.1002/path.5642 Epub ahead of print.

11. Hoffmann M, Kleine-Weber H, Schroeder S, et al. SARSCoV-2 cell entry depends on ACE2 and TMPRSS2 and is blocked by a clinically proven protease inhibitor. Cell. 2020;181:271-280.e8.

12. Heurich A, Hofmann-Winkler H, Gierer S, Liepold T, Jahn O, Pohlmann S. TMPRSS2 and ADAM17 cleave ACE2 differentially and only proteolysis by TMPRSS2 augments entry driven by the severe acute respiratory syndrome coronavirus spike protein. J Virol. 2014;88:1293-307.

13. Mahmoud IS, Jarrar YB, Alshaer W, Ismail S. SARS-CoV-2 entry in host cells - multiple targets for treatment and prevention. Biochimie. 2020;175:93-8.

14. Akira S, Uematsu S, Takeuchi O. Pathogen recognition and innate immunity. Cell. 2006;124:783-801.

15. Spuntarelli V, Luciani M, Bentivegna E, Marini V, Falangone F, Conforti G, et al. COVID-19: is it just a lung disease? A case-based review. SN Compr Clin Med. 2020:1-6. https://doi.org/10.1007/ s42399-020-00418-6 Innate immune response.

16. Konno Y, Kimura I, Uriu K, Fukushi M, Irie T, Koyanagi Y, et al. SARS-CoV-2 ORF3b is a potent interferon antagonist whose activity is increased by a naturally occurring elongation variant. Cell Rep. 2020;32:108185.

17. Xia H, Cao Z, Xie X, et al. Evasion of type I interferon by SARSCoV-2. Cell Rep. 2020;33:108234.

18. Lei X, Dong X, Ma R, et al. Activation and evasion of type I interferon responses by SARS-CoV-2. Nat Commun. 2020;11: 3810 .

19. Lei X, Dong X, Ma R, Wang W, Xiao X, Tian Z, et al. Activation and evasion of type I interferon responses by SARS-CoV-2. Nat Commun. 2020;11(1):3810. https://doi.org/10.1038/s41467-02017665-9.

20. Tian W, Zhang N, Jin R, Feng Y, Wang S, Gao S, et al. Immune suppression in the early stage of COVID-19 disease. Nat Commun. 2020;11(1):5859. https://doi.org/10.1038/s41467-020-19706-9.

21. Blanco-Melo D, Nilsson-Payant BE, Liu WC, et al. Imbalanced host response to SARS-CoV-2 drives development of COVID-19. Cell 2020; 181: 1036-1045.e9.

22. Zhang X, Tan Y, Ling Y, Lu G, Liu F, Yi Z, et al. Viral and host factors related to the clinical outcome of COVID-19. Nature. 2020;583:437-40.

23. Kurche JS, Haluszczak C, McWilliams JA, et al. Type I IFNdependent $\mathrm{T}$ cell activation is mediated by IFN-dependent dendritic cell OX40 ligand expression and is independent of T cell IFNR expression. J Immunol. 2012;188:585-93.

24. Helal MA, Shouman S, Abdelwaly A, Elmehrath AO, Essawy M, Sayed SM, et al. Molecular basis of the potential interaction of SARS-CoV-2 spike protein to CD147 in COVID-19 associatedlymphopenia. J Biomol Struct Dyn. 2020:1-11. https://doi.org/10. 1080/07391102.2020.1822208.
25. Fighting MC. COVID-19 exhausts T cells. Nat Rev Immunol. 2020;20:277.

26. Nienhold R, Ciani Y, Koelzer VH, et al. Two distinct immunopathological profiles in autopsy lungs of COVID-19. Nat Commun. 2020;11:5086.

27. van de Veerdonk FL, Janssen NAF, Grondman I, et al. A systems approach to inflammation identifies therapeutic targets in SARSCoV-2 infection. medRxiv. 2020. https://doi.org/10.1101/ 2020.05.23.20110916 Not peer reviewed.

28. Liu Q, Shi Y, Cai J, Duan Y, Wang R, Zhang H, et al. Pathological changes in the lungs and lymphatic organs of twelve COVID-19 autopsy cases. Natl Sci Rev. 2020;7:1868-78.

29. Bradley BT, Maioli H, Johnston R, Chaudhry I, Fink SL, Xu H, et al. Histopathology and ultrastructural findings of fatal COVID-19 infections in Washington state: a case series. Lancet. 2020;396: 320-32.

30. Smatti MK, Cyprian FS, Nasrallah GK, Al Thani AA, Almishal RO, Yassine HM. Viruses and Autoimmunity: A Review on the Potential Interaction and Molecular Mechanisms. Viruses. 2019;11: 762. https://doi.org/10.3390/v11080762.

31. Marks M, Marks JL. Viral arthritis. Clin Med (Lond). 2016;16: 129-34.

32. Hoang MP, Park J. Vasculitis. In: Hoang MP, Selim MA, editors. Hospital-based Dermatopathology: an illustrated diagnostic guide. Cham: Springer International Publishing; 2020. p. 245-96.

33. Ciaffi J, Meliconi R, Ruscitti P, Berardicurti O, Giacomelli R, Ursini F. Rheumatic manifestations of COVID-19: a systematic review and meta-analysis. BMC Rheumatol. 2020;4(1):65. https:// doi.org/10.1186/s41927-020-00165-0.

34. Zhou Y, Han T, Chen J, et al. Clinical and Autoimmune Characteristics of Severe and Critical Cases of COVID-19. Clin Transl Sci. 2020. https://doi.org/10.1111/cts.12805.

35. Zhang Y, Xiao M, Zhang S, Xia P, Cao W, Jiang W, et al. Coagulopathy and Antiphospholipid antibodies in patients with Covid-19. N Engl J Med. 2020;382:e38.

36. Zhou F, Yu T, Du R, et al. Clinical course and risk factors for mortality of adult inpatients with COVID-19 in Wuhan China: a retrospective cohort study. Lancet. 2020;395:1054-62.

37. Huang C, Wang Y, Li X, Ren L, Zhao J, Hu Y, et al. Clinical features of patients infected with 2019 novel coronavirus in Wuhan, China. Lancet. 2020;395:497-506.

38. Qin C, Zhou L, Hu Z, Zhang S, Yang S, Tao Y, et al. Dysregulation of immune response in patients with COVID-19 in Wuhan. China Clin Infect Dis. 2020;71:762-8. https://doi.org/10.1093/cid/ ciaa248.

39. Gao ZW, Wang X, Lin F, Dong K. The correlation between SARSCoV-2 infection and rheumatic disease. Autoimmun Rev. 2020;19: 102557. https://doi.org/10.1016/j.autrev.2020.102557.

40. Luciani M, Bentivegna E, Spuntarelli V, Amoriello Lamberti P, Guerritore L, Chiappino D, et al. Coinfection of Tuberculosis Pneumonia and COVID-19 in a Patient Vaccinated with Bacille Calmette-Guérin (BCG): Case Report. SN Compr Clin Med. 2020;17:1-4. https://doi.org/10.1007/s42399-020-00601-9 Epub ahead of print.

41. O'Neill LAJ, Netea MG. BCG-induced trained immunity: can it offer protection against COVID-19? Nat Rev Immunol. 2020;20: 335-7. https://doi.org/10.1038/s41577-020-0337-y.

42. Mazzotta C, Giancipoli E. Anterior Acute Uveitis Report in a SARS-CoV-2 Patient Managed with Adjunctive Topical Antiseptic Prophylaxis Preventing 2019-nCoV Spread Through the Ocular Surface Route. Int Med Case Rep J. 2020;13:513-20. https://doi.org/10.2147/IMCRJ.S260252.

Publisher's Note Springer Nature remains neutral with regard to jurisdictional claims in published maps and institutional affiliations. 